7. Cheng Y., Luo R., Wang K. et al. Kidney disease is associated with inhospital death of patients with COVID-19. Kidney Int. 2020. Vol. 97(5). P. 829-838. doi: 10.1016/j.kint.2020.03.005.

8. Zheng X., Yang H., Li X., Li H., et al. Prevalence of Kidney Injury and Associations with Critical Illness and Death in Patients with COVID-19. Clin J Am Soc Nephrol. 2020. Vol.15(11). P. 1549-1556. doi: 10.2215/ CJN.04780420.

9. Gabarre P., Dumas G., Dupont T., Darmon M., Azoulay E., Zafrani L. Acute kidney injury in critically ill patients with COVID-19. Intensive Care Med. 2020. Vol. 46(7). P.1339-1348. doi: 10.1007/s00134-020-06153-9.

10. Ronco C., Reis T. Kidney involvement in COVID-19 and rationale for extracorporeal therapies. Nat Rev Nephrol. 2020. Vol. 16(6). P.308-310. doi: 10.1038/s41581-020-0284-7.

11. Naicker S., Yang C.W., Hwang S.J., Liu B.C., Chen J.H., Jha V. The Novel Coronavirus 2019 epidemic and kidneys. Kidney Int. 2020. Vol. 97(5). P. 824-828. doi: 10.1016/j.kint.2020.03.001.

DOI https://doi.org/10.30525/978-9934-26-075-9-30

\title{
КОММУНИКАТИВНАЯ И КОНФЛИКТНАЯ КОМПЕТЕНТНОСТЬ ИНТЕРНОВ ЛЕЧЕБНОГО ПРОФИЛЯ
}

\author{
Хоботова Н. В. \\ кандидат медицинских наук \\ ассистент кафедры оториноларингологии \\ Днепровский государственный медииинский университет
}

Ехалов В. В.

кандидат медицинских наук,

доцент кафедры анестезиологии, интенсивной терапии и медицины неоткложных состояний Факультета последипломного образования Днепровский государственный медииинский университет

$$
\text { г. Днепр, Украина }
$$

Острота противоречий между качественными изменениями в медицине и установившимися в обществе моральными ценностями привела к формированию комплекса неоднозначных в этическом отношении проблем [1]. Этот процесс в области здравоохранения обусловлен рядом причин, которые являются следствием субъективных, 
организационных, экономических, деонтологических, диагностических, лечебных, профилактических действий сфер организации оказания медицинской помощи, а также психологических факторов, которые могут быть вызваны просчетами руководства [2]. К объективным причинам можно отнести обстоятельства социального взаимодействия людей, которые приводят к столкновению их интересов, мнений, установок. Особое значение имеет несовершенство нормативной базы в области здравоохранения, низкое качество образования отдельных медицинских работников, расширение спектра платных услуг, деструктивное влияние средств массовой информации, усиливающих конфликтное противостояние. Если ранее конфликтная ситуация получала развитие только в личном общении врача и больного с привлечением в качестве арбитра администрации лечебного учреждения, то в настоящее время случаи взаимного непонимания все чаще заканчиваются в суде [3, 4].

Цель исследования: изучение в динамике уровня коммуникативной и конфликтной компетентности врачей-интернов лечебного профиля за время обучения, сформулировать ближайший и отдалённый прогноз их адаптационных возможностей в условиях практической врачебной деятельности.

Материалы и методы: за последние 2 года было анонимно протестировано 300 врачей интернов лечебного профиля 1-го и 2-го года обучения и проведен анализ эмпирических данных, полученных с помощью методики диагностирования склонности личности к конфликтному поведению предложенной К. Томасом и адаптированной Н.В. Гришиной [5].

Таблица 1

\section{Распределение показателей конфликтности среди врачей-интернов}

\begin{tabular}{|c|c|c|c|c|c|c|c|c|c|c|}
\hline $\begin{array}{c}\text { Пока- } \\
\text { затель } \\
\end{array}$ & \multicolumn{2}{|c|}{$\begin{array}{c}\text { Конфрон- } \\
\text { тация } \\
\end{array}$} & \multicolumn{2}{|c|}{$\begin{array}{c}\text { Сотруд- } \\
\text { ничество } \\
\end{array}$} & \multicolumn{2}{|c|}{$\begin{array}{l}\text { Компро- } \\
\text { мисс }\end{array}$} & \multicolumn{2}{|c|}{$\begin{array}{c}\text { Избега- } \\
\text { ние }\end{array}$} & \multicolumn{2}{|c|}{$\begin{array}{l}\text { Приспо- } \\
\text { собление }\end{array}$} \\
\hline $\begin{array}{c}\text { Год } \\
\text { обучения }\end{array}$ & 1-й & 2-й & 1-й & 2-й & 1-й & 2-й & 1-й & 2-й & 1-й & 2-й \\
\hline $\begin{array}{c}\text { Maximal } \\
\text { Склон- } \\
\text { ность }\end{array}$ & $\begin{array}{c}23,9 \\
\%\end{array}$ & $\begin{array}{l}17, \\
2 \%\end{array}$ & $\begin{array}{l}17, \\
6 \%\end{array}$ & $\begin{array}{c}27,3 \\
\%\end{array}$ & $\begin{array}{l}80, \\
5 \%\end{array}$ & $\begin{array}{c}78,9 \\
\%\end{array}$ & $\begin{array}{l}59, \\
8 \%\end{array}$ & $\begin{array}{l}25, \\
3 \%\end{array}$ & $\begin{array}{l}19, \\
6 \%\end{array}$ & $\begin{array}{l}19, \\
6 \%\end{array}$ \\
\hline $\begin{array}{c}\text { Minimal } \\
\text { склонност } \\
\text { b }\end{array}$ & $\begin{array}{c}49,9 \\
\%\end{array}$ & $\begin{array}{l}54, \\
1 \%\end{array}$ & - & - & - & - & - & $\begin{array}{l}16, \\
1 \%\end{array}$ & $\begin{array}{l}25, \\
5 \%\end{array}$ & $\begin{array}{l}24, \\
1 \%\end{array}$ \\
\hline $\begin{array}{c}\text { Средний } \\
\text { показатель }\end{array}$ & $\begin{array}{c}13,7 \\
\%\end{array}$ & $\begin{array}{l}9,9 \\
\%\end{array}$ & $\begin{array}{l}19, \\
8 \%\end{array}$ & $\begin{array}{c}29,3 \\
\%\end{array}$ & $\begin{array}{l}26, \\
9 \%\end{array}$ & $\begin{array}{c}27,1 \\
\%\end{array}$ & $\begin{array}{l}23, \\
5 \%\end{array}$ & $\begin{array}{l}19, \\
1 \%\end{array}$ & $\begin{array}{l}16, \\
1 \%\end{array}$ & $\begin{array}{l}14, \\
6 \%\end{array}$ \\
\hline
\end{tabular}




\section{Результаты и обсуждения.}

Интерны лечебного профиля представляют собой профессиональную среду на границе между студентами и врачами практической медицины, a с точки зрения образовательных характеристик - между педагогическими и андрагогическими субъектами обучения.

Превалирование духа соперничества указывает на повышенную агрессивность и настойчивость на собственной точке зрения, что способно провоцировать конфликтные ситуации [6]. Конфронтация предполагает сосредоточение внимания только на своих интересах и полное игнорирование ценностей партнёра [3]. Что касается склонности опрошенных интернов к соперничеству, то полученные сведения характеризуются значительным расхождением: максимальную склонность к соперничеству показали $23,9 \%$ интернов 1-го года обучения, а минимальную - 49,9\%, к концу 2-го года образовательного процесса показатели стали $17,2 \%$ и 54,1\% соответственно. Среднее же значение характеристики в конце обучения в интернатуре снизилось лишь на $3,8 \%$.

Человеку, который предпочитает стиль сотрудничества, свойственен поиск информации и выявления собственной позиции без морального столкновения. Конструктивное взаимовыгодное решение конфликта не только помогает избежать нежелательных последствий, но и позволяет сохранять хорошие отношения между сторонами. В результате такого подхода появляются новые идеи, творческое сотрудничество, взаимное удовлетворение интересов [3,7]. Максимальная склонность к сотрудничеству у интернов на втором году обучения выросла с 17,6\% до 27,3\% при увеличении среднего показателя с 19,8\% до 29,3\%.

Существует мнение, что избегание конфликта способно снизить взаимное напряжение. Это не совсем так. Очень часто разногласия усугубляются, поскольку партнёр, бесполезно ожидая ваших действий, остается неудовлетворенным, что порождает стойкое напряжение и новые проблемы [7]. Исходная склонность большинства респондентов к избеганию конфликта к концу обучения упала более, чем вдвое, при небольшом снижении среднего показателя на 4,4\%.

Человек, который склонен к приспособлению, во время конфликта отказывается от своих интересов ради интересов другого человека, для того, чтобы сохранить с ним хорошие отношения. Такое поведение в конфликтных ситуациях целесообразно только в отношениях с близкими людьми, особенно когда необходима помощь и поддержка для слабого и больного. Но если такой стиль использовать постоянно, то это может привести к постоянному проигрышу во всех делах и начинаниях [7]. Максимальная склонность к приспособлению у 16,6\% респондентов практически не изменялась к концу обучения при небольшом снижении среднего показателя с 16,1\% до 14,6. 
Анализ склонности к конфликтам, проведенный по данным анонимного анкетирования показал низкий уровень конфликтности в среде интернов разных специальностей 1-го года обучения. По средним показателям в респонденты 1-го года обучения показали самую высокую склонность к компромиссу и избеганию конфликта, но по окончании интернатуры способность к сотрудничеству значительно возросла. По К. Томасу [5] такие способы регулирования конфликтов, как соперничество, приспособление и уклонение, имеют деструктивный характер, поскольку в конфликтной ситуации или проигрывает один из ее участников, а второй выигрывает, или проигрывают оба, потому что идут на компромиссные поступки. И только сотрудничество и, в меньшей мере, компромисс являются продуктивным поведением в конфликтной ситуации $[3,8]$.

Проблема молодого специалиста заключается в его практически полной некомпетентности в производственных межличностных отношениях. Вопросы коммуникации врача и пациента сегодня в процессе обучения обычно рассматриваются только с позиций этики и деонтологии $[9,10,11]$. В результате выпускник интернатуры абсолютно не знаком со стратегиями и тактиками коммуникации при общении с конфликтным или манипулирующим пациентом.

Современные психологические исследования проявления конфликтных форм поведения позволяют разработать эффективную психокоррекционную программу. Научить людей новому поведению реально только в том случае, если они сами хотят меняться. В немалой степени успехи учебных программ, особенно тренинговых, объясняются тем, что люди, которые приходят в эти группы, уже ориентированы на собственное изменение и восприятие нового. Остаётся лишь открытым вопрос как побудить к изменениям тех, кто к этому не склонен [5]. В такой ситуации большое значение имеет мотивация молодых коллег к овладению не только профессиональными знаниями и навыками, но и навыкам поведения в социуме, что должно быть доведено до сознания студентов с начальных курсов $[17,18]$.

\section{Выводы:}

1. Проведенное исследование степени конфликтности современных врачей-интернов показало достаточно низкий уровень коммуникативной и конфликтной компетентности молодых коллег.

2. Обучение в интернатуре характеризуется положительной динамикой в плане снижения склонности молодых коллег к конфронтации в пользу повышения стремления к сотрудничеству как оптимальной стратегии социального поведения.

3. Современное состояние обсуждаемого вопроса требует поиска новых путей коррекции основ социального поведения будущих практических врачей. 


\section{Литература:}

1. Синюкова Н.А. Этические комитеты и конфликты современной медицины. Journal of Siberian Medical Sciences. 2018. № 2. C. 64-71.

2. Гуренко-Вайцман М. Н., Сугробова Ю. Ю., Юриста А. В. Проблематика конфликтов в социо-культурном пространстве современного отечественного здравоохранения. Таврический медико-биологический вестник, 2017. т. 20. №2. С. 202-207.

3. Конфликтные ситуации в медицинской практике: этические и правовые аспекты/ Усенко Л.В., Кобеляцкий Ю.Ю., Клопоцкая Н.Г., Царев А.В., Усенко А.А., Оленюк Д.В. Медиџина невідкладних станів, 2020. T. 16, № 1. C. 115-119. DOI: 10.22141/2224-0586.16.1.2020.196939

4. Коберник Л.О. Психологія прояву конфліктних форм поведінки в

студентському віці. Практична психологія в системі вищої освіти: теорія, результати досліджень, технології: монографія /за ред. проф. Н.І.Пов'якел. - К.: НПУ ім. М.П.Драгоманова, 2009. С. 232-240.

5. Гришина Н. В. Психология конфликта. 2-е изд. СПб.: Питер, $2008.544 \mathrm{c}$.

6. Котлова Л.О. Психологічні особливості конфліктних форм поведінки студентів та їх особистісного статусу. Наукові записки Вінницького державного педагогічного університету імені М. Коиюбинського. Серія: Педагогіка і психологія: Зб. наук. праць. вип. 32. Вінниця: ТОВ фірма «Планер», 2010. С. 444-450.

7. Мазяр О.В., Бученко Л.І. Особливості конфліктної поведінки підлітків в залежності від рівня навчальної успішності. Житомир, 2009. C. 33-35.

8. Корніяка О.М. Вивчення розвитку комунікативної компетентності студентів. Психолінгвістика: Зб. наук. пращь ДВНЗ «Переяслав-

Хмельнииький державний педагогічний університет ім. Г. Сковороди». Переяслав-Хмельницький: ПП «СКД», 2009. вип. 3. С. 60-69.

9. Схалов В. В., Клигуненко О. М., Муризіна О. Ю. Медична деонтологія очима лікаря за фахом "Загальна практика-сімейна медицина". Сімейна медицина, 2015. № 6. С. 33-35.

10. Деонтологічні та індивідуально-психологічні аспекти підготовки майбутніх лікарів хірургічних спеціальностей/ Бараннік С.І., Стусь В.П., Трофімов М.В., Схалов В.В., Бараннік К.С. Медичний форум, 2017. № 11. C. 5-8.

11. Схалов В.В., Павлиш О.С., Сгоров С.В. Медична етика та деонтологія в практиці лікаря - дитячого анестезіолога. Медищина невідкладних станів, 2019. № 3 (98). С. 137-139. DOI: 10.22141/22240586.3.98.2019.165489

12. Манхейм К. Избранное: Диагноз намего времени / пер. с нем. и англ. М.: Изд. «РАО Говорящая книга», 2010. 744 с.

13. Yekhalov V.V., Kravets O.V., Krishtafor D. A. Psychological Features of the Modern Intern. The world of science and innovation. Abstracts of the $6^{\text {th }}$ 
International scientific and practical conference. Cognum Publishing House. London, United Kingdom, 2021. P. 304-311.

14. Певні якості мислення у лікарів-інтернів різних фахів/ Стусь В.П., Схалов В.В., Моісеєнко М.М., Романюта I.А., Бараннік С.І. Урологія, 2020. т. 24. №2. C. 180-185. DOI: 10.26641/2307-5279.24.2.2020.208835

15. Новикова С.Г. Конфликтный больной на врачебном приеме. Как решить возникшие проблемы? Хирургическая практика, 2019. № 1(37). C.48-57. DOI: 10.17238/issn2223-2427.2019.1.48-57

16. Особливості психоемоційної підготовки лікарів- інтернів до самостійної праці як фахівців на рівні міжнародних вимог / Хавалкіна Л. М., Удальцова-Гродзинська К. О., Тимошенко Ю. В. Сучасна медична освіта: методологія, теорія, практика : матеріали Всеукр. навч.-наук. конф. $з$ міжнар. участю, м. Полтава (19 березня 2020 р.). Полтава, 2020. C. 235-237.

17. Схалов В.В., Кравець О.В., Богатирьова О.В. Принцип междисціпланарної інтеграції та апріорної мотивації в медицині невідкладних станів. Медичні перспективи, 2014, том XIX . № 2. Ч. 1. С. 103-105.

18. Yekhalov V. V., Sedinkin V. A. Present Day Deviations of Thinking of the Internship Doctors. International Journal of Science Annals, 2020. т.3. №1. C. 57-59. DOI:10.26697/ijsa

DOI https://doi.org/10.30525/978-9934-26-075-9-31

\title{
ЯКІСТЬ ЖИТТЯ У ЧОЛОВІКІВ, ХВОРИХ НА АНКІЛОЗИВНИЙ СПОНДИЛІТ, ЗВ'ЯЗОК З АКТИВНІСТЮ ЗАХВОРЮВАННЯ ТА СТРУКТУРНО-ФУНКЦІОНАЛЬНИМ СТАНОМ КІСТКОВОЇ ТКАНИНИ
}

\author{
Шевчук С. В. \\ доктор медичних наук, професор, \\ завідувач кафедри внутрішньої медицини № 2
}

Вінницький національний медичний університет імені М. І. Пирогова

Павлюк О. М.

аспірант кафедри внутрішньої медицини № 2

Вінницький національний медичний університет імені М. І. Пирогова м. Вінниця, Україна

Вступ. Оцінка якості життя (ЯЖ), що пов'язана зі здоров'ям, набуває все більшого значення при анкілозивниму спондиліті (АС). Біль, загальна 124 